\title{
Assessment of pulmonary macrophage and neutrophil function in sequential bronchoalveolar lavage aspirates in sarcoidosis
}

\author{
C A KELLY, C WARD, S C STENTON, D J HENDRICK, E H WALTERS \\ From the Department of Medicine, Newcastle General Hospital and University of Newcastle upon Tyne
}

ABSTRACT Bronchoalveolar lavage was performed in eight patients with biopsy proved sarcoidosis and eight control subjects matched for age and smoking habit, three sequential $60 \mathrm{ml}$ aliquots of sterile saline being used. Each aliquot was aspirated and analysed separately to determine total and differential cell counts. Cellular metabolic activity was stimulated with latex and measured by means of luminol enhanced chemiluminescence to assess neutrophil activity and lucigenin enhanced chemiluminescence to assess macrophage activity. In control subjects mean total cell counts were significantly greater in the second aspirate than in the first, but fell slightly in the third. Similarly, in the patients with sarcoidosis mean total cell counts increased from aspirate 1 to a maximum in aspirate 2 , before falling again marginally in aspirate 3 . The only significant difference in cell counts between patients with sarcoidosis and controls was an approximately threefold increase in total lymphocyte counts in the former in each of the three aspirates. Luminol chemiluminescence was similar in patients with sarcoidosis to that in controls in the first aspirate, but was significantly greater in the second and third aspirates. Lucigenin chemiluminescence was also significantly greater in the second and third aspirates only. Thus in patients with sarcoidosis lymphocyte numbers are increased in all three aspirates whereas cellular metabolic activity is increased to a greater extent in later aspirates, which may reflect events occurring in the periphery of the lung segment.

\section{Introduction}

The alveolar pulmonary macrophage and lymphocyte have been implicated in the pathogenesis of pulmonary sarcoidosis, ${ }^{1-3}$ but the role of the neutrophil in the production of lung damage in sarcoidosis is less well established. ${ }^{4}$ In a recent study luminol enhanced chemiluminescence was found to be increased in cells obtained at bronchoalveolar lavage, and was interpreted as confirmation of increased macrophage activity'; there is evidence, however, that luminol chemiluminescence is myeloperoxidase dependent ${ }^{6}$ and reflects exclusively neutrophil activity in lavage fluid. ${ }^{7}$ Lucigenin enhanced chemiluminescence is probably mediated by superoxide radical release $^{8}$ and can be used as an index of alveolar

Address for reprint requests: Dr E H Walters, Department of Medicine, Newcastle General Hospital, Newcastle upon Tyne NE4 6BE.

Accepted 10 June 1988 macrophage activity. ${ }^{9}$ We have shown in pure cell populations that luminol chemiluminescence is specific for neutrophil activity, and that lucigenin chemiluminescence provides a reasonable but slightly less specific index of macrophage function. ${ }^{10} \mathrm{We}$ have adopted these indices to assess the metabolic activity of neutrophils and macrophages in lavage fluid. It has been suggested that, when successive $60 \mathrm{ml}$ aliquots of saline are introduced into a segment of the middle lobe, aspiration of the first aliquot obtains cells largely from the major airways and aspiration of subsequent aliquots obtain more cells from the alveoli." Using computerised subtraction radiology, we have recently shown that the kinetics of fluid introduced and aspirated at lavage are consistent with an increasingly alveolar wash with increasing volume of introduced fluid. ${ }^{12}$ We have therefore applied a standard technique of three sequential $60 \mathrm{ml}$ lavages at one site to eight patients with stable sarcoidosis to confirm the value of chemiluminescence in assessing phagocytic activity in sarcoidosis, and to determine the site of maximal cellular activity. 


\section{Methods}

We recruited eight consecutive patients (mean age 40.6 years), two of them smokers, attending the chest clinic at Newcastle General Hospital with biopsy proved, active sarcoidosis with pulmonary lesions. The mean duration of disease was 12 (range 4-30) months. None of the patients was taking corticosteroids, although two had received them until 18 and 24 months previously. Clinical details and radiological staging are shown in table 1 . Eight age and sex matched normal control subjects (mean age 41 years), two of them smokers, were recruited from patients who had undergone diagnostic bronchoscopy for investigation of haemoptysis but in whom no abnormalities had been found. These subjects had normal results in pulmonary function tests and no other evidence of pulmonary disease. Ethical committee approval and individual informed consent were obtained.

A segment of the middle lobe was lavaged with sterile buffered saline, warmed to $37^{\circ} \mathrm{C}$, in three aliquots of $60 \mathrm{ml}$. Each aliquot was promptly aspirated into separate siliconised glass bottles kept at $4^{\circ} \mathrm{C}$. After filtration through a $200 \mu \mathrm{m}^{2}$ sterile steel mesh, total cell counts were performed on each aspirate by two independent observers using a Neubauer counting chamber. The mean values are expressed as cells $\times 10^{5} / \mathrm{ml}$. The aspirates were centrifuged at $400 \mathrm{~g}$ for five minutes, and the cell pellets were individually resuspended at a concentration of $5 \times 10^{5} / \mathrm{ml}$ in Medium 199. Cell viability was assessed by tryphan blue exclusion, and cytospin preparations were made with a Shandon II Cytospin with $100 \mu \mathrm{l}$ of each cell suspension. The slides were stained with Wright-Giemsa and differential cell counts were performed on 300 cells by the same observers. The mean values are expressed in absolute $\left(\times 10^{5} / \mathrm{ml}\right)$ and percentage terms.

The cell suspension $(500 \mu \mathrm{l})$ was added to $900 \mu \mathrm{l}$ of $10^{-4}$ solutions of either luminol or lucigenin, and warmed to $37^{\circ} \mathrm{C}$. After the addition of $100 \mu l$ unop- sonised $5 \%$ latex particles (Sigma Chemicals) chemiluminescence was measured by an LKB 1250 등 luminometer. Cell suspensions from each aspirate $\frac{\overline{\bar{\alpha}}}{\overline{0}}$ were assayed in triplicate, and the mean peak height ${ }_{\bar{\sigma}}$ of each response was recorded in mv. This was expressed as CL per 1000 neutrophils for luminoles and per 1000 macrophages for lucigenin to exclude $\vec{\circ}$ variations due to differing cells profiles.

Statistical comparison between the control subjects $\vec{\rho}$ and patients with sarcoidosis was performed with the Wilcoxon rank test, and intragroup comparison with. Student's paired $t$ test.

\section{Results}

The mean total cell count in aspirate 1 from patients with sarcoidosis was not significantly different from that of the control subjects. The mean total cell count rose significantly in the second aspirate in both 0 the sarcoidosis and the control group ( $p<0.05$ for $\mathbb{\Phi}$ each comparison). In the controls this was largely $\vec{P}$ due to an increase in the absolute number of macro- $\infty$ phages, but in the patients with sarcoidosis there was a significant increase in the absolute numbers of both macrophages and lymphocytes (table $2 a$ ). In contrast, there was a significant fall in the absolute numbers of neutrophils in the second aspirates in $\%$ each group ( $\mathrm{p}<0.05$ ), as shown in table $2 a$. In both $\stackrel{\unrhd}{\varrho}$ groups the absolute and differential cell counts in the $\overrightarrow{\vec{O}}$ third aspirate were similar to those in the second 3 aspirate.

The only significant differences in cell counts between the two groups was that the mean lymphocyte count was higher in the patients with sarcoidosis than in the control group (p<0.01) in each of the $\stackrel{x}{x}$ three aspirates. The percentage lymphocyte count $\frac{0}{3}$ was reasonably consistent in each aspirate in both the patients with sarcoidosis (32-38\%) and the control subjects (15-18\%) (table $2 b$ ).

Cell viability was at least $92 \%$ in all specimens. In 은 the control group both luminol and lucigenin $\rightarrow$ chemiluminescence remained relatively constant in

Table 1 Details of the clinical state and results of investigations on eight patients with biopsy proved sarcoidosis, including overall mean values for luminol and lucigenin $(C L)$

\begin{tabular}{|c|c|c|c|c|c|c|c|}
\hline $\begin{array}{l}\text { Patient } \\
\text { No }\end{array}$ & Sex & $\operatorname{Age}(y)$ & $\begin{array}{l}\text { Kveim } \\
\text { test }\end{array}$ & Stage & $\begin{array}{l}\text { Lavage } \\
\text { lymphocytes (\%) }\end{array}$ & $\begin{array}{l}\text { Luminol } \\
C L\left(m V / 10^{3} \mathrm{~N}\right)\end{array}$ & $\begin{array}{l}\text { Lucigenin } \\
C L\left(\mathrm{mV} / 10^{6} \mathrm{M}\right)\end{array}$ \\
\hline $\begin{array}{l}1 \\
2 \\
3 \\
4 \\
5 \\
6 \\
7 \\
8\end{array}$ & $\begin{array}{l}\mathbf{F} \\
\mathbf{F} \\
\mathbf{F} \\
\mathbf{F} \\
\mathbf{M} \\
\mathbf{M} \\
\mathbf{M} \\
\mathbf{M}\end{array}$ & $\begin{array}{l}58 \\
31 \\
35 \\
40 \\
35 \\
42 \\
42 \\
42\end{array}$ & $\begin{array}{l}\text { ND } \\
\text { ND } \\
\text { ND } \\
+ \\
+ \\
\text { ND } \\
\text { ND } \\
+\end{array}$ & $\begin{array}{l}3 \\
1 \\
1 \\
2 \\
2 \\
3 \\
3 \\
3\end{array}$ & $\begin{array}{l}36 \\
37 \\
20 \\
14 \\
16 \\
35 \\
63 \\
40\end{array}$ & $\begin{array}{l}0.22 \\
0.48 \\
0.60 \\
0.40 \\
0.27 \\
0.60 \\
0.48 \\
0.18\end{array}$ & $\begin{array}{r}38 \\
18 \\
50 \\
110 \\
158 \\
20 \\
20 \\
15\end{array}$ \\
\hline
\end{tabular}

+ indicates positive results.

$\mathrm{ND}$-not done; $\mathrm{N}$-neutrophils; $\mathrm{M}$-macrophages. 
Pulmonary macrophage and neutrophil function in sequential bronchoalveolar lavage aspirates in sarcoidosis 789

Table 2 Mean (SD) absolute and percentage cell counts in each aliquot aspirated from control subjects and patients with sarcoidosis

\begin{tabular}{|c|c|c|c|c|c|c|}
\hline & Macrophages & Lymphocytes & Neutrophils & Eosinophils & Epithelial cells & Total \\
\hline \multicolumn{7}{|c|}{ (a) Absolute cell counts $\left(\times 10^{5} / \mathrm{ml}\right)$} \\
\hline $\begin{array}{l}\text { SARCOIDOS } \\
\text { Aliquot 1 } \\
\text { Aliquot } 2 \\
\text { Aliquot } 3 \\
\text { Mean }\end{array}$ & $\begin{array}{l}0.63(0.4)^{*} \\
1.06(0.4)^{*} \\
0.87(0.5) \\
0.91(0.4)\end{array}$ & $\begin{array}{l}0.40(0.3)^{*} \\
0.68(0.4)^{*} \\
0.72(0.7) \\
0.65(0.5)\end{array}$ & $\begin{array}{l}0.09(0.10)^{*} \\
0.02(0.01)^{*} \\
0.03(0.01) \\
0.03(0.02)\end{array}$ & $\begin{array}{l}0.02(0.02) \\
0 \\
0 \\
0.01(0.01)\end{array}$ & $\begin{array}{l}0.10(0.07) \\
0.05(0.05) \\
0.04(0.05) \\
0.05(0.05)\end{array}$ & $\begin{array}{l}1.24(0.8)^{*} \\
1.81(0.9)^{*} \\
1.67(1.3) \\
1.65(1.0)\end{array}$ \\
\hline $\begin{array}{l}\text { CONTROL } \\
\text { Aliquot } 1 \\
\text { Aliquot } 2 \\
\text { Aliquot } 3 \\
\text { Mean }\end{array}$ & $\begin{array}{l}0.71(0.6)^{*} \\
1.45(1.3)^{*} \\
1.20(1.0) \\
1.25(1.1)\end{array}$ & $\begin{array}{l}0.13(0.07) \\
0.20(0.1) \\
0.25(0.2) \\
0.19(0.1)\end{array}$ & $\begin{array}{l}0.08(0.06)^{*} \\
0.05(0.04)^{*} \\
0.04(0.06) \\
0.05(0.05)\end{array}$ & $\begin{array}{l}0.01(0.01) \\
0 \\
0 \\
0\end{array}$ & $\begin{array}{l}0.07(0.04) \\
0.03(0.04) \\
0.05(0.02) \\
0.04(0.03)\end{array}$ & $\begin{array}{l}1.00(0.8)^{*} \\
1.73(1.5)^{*} \\
1.54(1.1) \\
1.53(1.2)\end{array}$ \\
\hline \multicolumn{7}{|c|}{ (b) Percentage cell counts } \\
\hline $\begin{array}{l}\text { SARCOIDOS } \\
\text { Aliquot } 1 \\
\text { Aliquot } 2 \\
\text { Aliquot } 3 \\
\text { Mean }\end{array}$ & $\begin{array}{l}52(12) \\
60(13) \\
61(15) \\
60(14)\end{array}$ & $\begin{array}{l}32(16) \\
35(19) \\
37(20) \\
35(18)\end{array}$ & $\begin{array}{l}6(7) \\
1(1) \\
1(1) \\
2(2)\end{array}$ & $\begin{array}{l}2(2) \\
0 \\
0 \\
0.4(0.3)\end{array}$ & $\begin{array}{l}8(8) \\
4(2) \\
1(1) \\
2 \cdot 6(2)\end{array}$ & \\
\hline $\begin{array}{l}\text { CONTROL } \\
\text { Aliquot } 1 \\
\text { Aliquot } 2 \\
\text { Aliquot } 3 \\
\text { Mean }\end{array}$ & $\begin{array}{l}65(18) \\
78(11) \\
81(10) \\
77(12)\end{array}$ & $\begin{array}{l}16(9) \\
15(11) \\
17(11) \\
15(10)\end{array}$ & $\begin{array}{l}9(8) \\
2(3) \\
2(2) \\
3(4)\end{array}$ & $\begin{array}{l}1(2) \\
0 \\
0 \\
0 \cdot 2(0 \cdot 2)\end{array}$ & $\begin{array}{l}9(8) \\
5(4) \\
0 \\
3 \cdot 8(3)\end{array}$ & \\
\hline
\end{tabular}

*Significant difference between aliquots 1 and 2 in both control and sarcoidosis groups by Student's paired $t$ test (p<0.05).

each aspirate (table 3). The differences between control subjects and patients with sarcoidosis in the values of both luminol and lucigenin chemiluminescence from cells in the first aspirate failed to achieve significance. In the second aspirate, however, luminol chemiluminescence was significantly greater in patients with sarcoidosis than in controls $(p<0.05)$. Lucigenin chemiluminescence was also significantly greater in patients with sarcoidosis in the second aspirate than in controls subjects $(p<0.01)$. Both luminol and lucigenin chemiluminescence were also significantly increased in the third aspirate in patients with sarcoidosis.

Table 3 Median (with ranges) luminol chemiluminescence (CL) (per 1000 neutrophils) and lucigenin CL (per 1000 macrophages) in each aliquot aspirated from control subjects and patients with sarcoidosis

\begin{tabular}{lll}
\hline & Sarcoidosis & \multicolumn{1}{l}{ Control } \\
\hline LUMINOL CL $\left(\mathrm{mV} / 10^{3} \mathrm{~N}\right)$ & & \\
Aliquot 1 & $0.42(0.02-0.9)$ & $0.36(0.01-0.88)$ \\
Aliquot 2 & $0.64(0.38-3.2)^{*}$ & $0.25(0.04-0.68)$ \\
Aliquot 3 & $0.58(0.14-2.4)^{*}$ & $0.29(0.04-0.70)$ \\
LucigenIN CL (mv/103 & & \\
Aliquot 1 & $0.014(0.001-0.03)$ & $0.008(0.001-0.02)$ \\
Aliquot 2 & $0.022(0.013-0.10)^{*}$ & $0.007(0.001-0.03)$ \\
Aliquot 3 & $0.032(0.010-0.06)^{*}$ & $0.008(0.001-0.03)$ \\
\hline
\end{tabular}

Difference between patients with sarcoidosis and control subjects by the Wilcoxon rank test $(p<0.05)$.

$\mathrm{N}$-neutrophils; $\mathrm{M}$-macrophages.

\section{Discussion}

An increase in the absolute and percentage number of lymphocytes is an invariable finding in lavage fluid from patients with active sarcoidosis. ${ }^{13}$ In the current study this change was found in sequential aspirates, which are generally thought to reflect events occurring at different anatomical levels ${ }^{11}{ }^{12}$-hence the increase in lymphocytes is non-specific and present throughout the bronchoalveolar segment. The total cell counts in both groups were greater in the second and third aspirates than in the first, and this is consistent with previous observations. ${ }^{14} \mathrm{~A}$ reduction in neutrophil numbers after the first aspirate has also been described. ${ }^{15}$

In the present study the chemiluminescence generated by both neutrophils and macrophages was greater in cells from patients with sarcoidosis than in cells from the control group in each aspirate, confirming that both cell types are activated in sarcoidosis. The differences between the groups were more striking and achieved significance only in the second and third aspirates, suggesting that not only are both cell types activated in the lungs in sarcoidosis ${ }^{5}$ but that cell activation is predominantly found in the distal airways and alveoli. This is consistent with the findings of pathological studies of lungs in patients with sarcoidosis. ${ }^{16}$

Luminol chemiluminescence has been used to assess neutrophil activity in several different conditions, ${ }^{17}{ }^{18}$ although eosinophils may also contribute 
when present in sufficient numbers. Eosinophils comprised only $0.4 \%$ of the total cell population in the patients with sarcoidosis and were most evident in the first aspirate, where chemiluminescence was lowest. They are therefore unlikely to have influenced our results. Only small amounts of luminol chemiluminescence are generated by macrophages from lavage fluid, ${ }^{5}$ and the luminol chemiluminescence attributed to macrophages by Martin et al was almost certainly due to neutrophils. Lucigenin chemiluminescence has been used as an index of alveolar macrophage activity in several disorders, ${ }^{1920}$ and is unlikely to have been influenced by the numbers of granulocytes present in this study. ${ }^{10}$ The expression of chemiluminescence per 1000 cells is more specific than total chemiluminescence, as it overcomes the variable composition of lavage aspirates. The same results, however, are obtained if the data are expressed as total chemiluminescence (per 250000 cells).

Chemiluminescence provides a useful method of assessing cellular metabolic activity, especially as it requires minimal cell preparation, although it does not afford a global measure of cell function. As part of the interstitial lung damage in sarcoidosis may be mediated by toxic oxygen species, chemiluminescence seems a logical means of assessing disease activity. Our study not only indicates lavage neutrophil activation in sarcoidosis but suggests that pulmonary macrophages are also activated. This increase in macrophage activity may be highly relevant to the pathogenesis of sarcoidosis as pulmonary macrophages are known to play an important part in antigen presentation to $\mathrm{T}$ lymphocyte ${ }^{21}$ and stimulation of $T$ cell proliferation, ${ }^{22}$ and are known to express an increased density of surface markers. ${ }^{23}$ Although our patients with sarcoidosis covered a wide range in terms of radiological staging, this did not relate to disease activity in our small group. The increase in cellular metabolic activity appeared to be greatest in the lung periphery, in keeping with the idea that inflammatory alveolitis forms a central feature of the disease process.

\section{References}

1 Crystal RG, Bitterman PB, Rennard SI, Hance AJ, Keogh BA. Interstitial lung disease of unknown cause. Diseases characterised by chronic inflammation of the lower respiratory tract. $N$ Engl J Med 1984;310:154, 235-44.

2 Daniels RP, Dauber JH, Rossman MD. Immunologic abnormalities in sarcoidosis. Ann Intern Med 1980; 92:406-16.

3 Hance AJ, Douches S, Winchester RJ, Ferrans VJ, Crystal RG. Characterization of monoclonal phagocytic subpopulations in the human lung by using monoclonal antibodies: changes in alveolar macro- $\rightarrow$ phage phenotype associated with pulmonary sar-드 coidosis. J Immunol 1985;134:284-91.

4 Keogh BA, Hunninghake GW, Line BR, Crystal RG. The alveolitis of pulmonary sarcoidosis: evaluation of natural history and alveolitis dependent changes in lung function. Am Rev Respir Dis 1983;128:256-65.

5 Martin RR, Lawrence EC, Teague RB, Gottlieb MS, $\vec{\circ}$ Putman M. Chemiluminescence of lung macrophages $\overrightarrow{-}$ and blood leucocytes in sarcoidosis. Am Rev Respir Dis $\vec{\omega}$ 1986;133:298-301.

6 Dahlgren C, Stendahl O. Role of myeloperoxidase in $\overrightarrow{\vec{x}}$ luminol-dependent chemiluminescence of polymor- $\vec{\omega}$ pholeukocytes. Infect Immunol 1983;39:736-41.

7 Williams AJ, Cole PJ. Human bronchoalveolar lavage? cells and luminol dependent chemiluminescence. J Clin $\infty$ Pathol 1981;34:167-71.

8 Allen RC. Biochemiexcitation: chemiluminescence and $\stackrel{ }{2}$ the study of biological oxygen reactions. In: Adam W, $\rightarrow$ Cilento G, eds. Chemical and biological generation. New York: Academic Press, 1982:309-44.

9 Williams AJ, Cole PJ. In vitro stimulation of alveolar macrophage metabolic activity by polystyrene in the absence of phagocytosis. Br J Exp Pathol 1981;62:1-7. $\vec{\varphi}$

10 Ward C, Kelly CA, Stenton CS, Duddridge M, Hendrick $\infty$ DJ, Walters EH. Macrophage and neutrophil chemiluminescence in bronchoalveolar lavage fluid. Clin Sci 1987;73:33-4.

11 Lam S, Leriche JC, Kijek K, Phillips D. Effect of $\overline{\bar{O}}$ bronchial lavage volume on cellular and protein $\stackrel{2}{(1)}$ recovery. Chest 1985;88:856-9.

12 Kelly CA, Kotre JC, Ward C, Hendrick DJ, Walters EH. $\overrightarrow{\vec{O}}$ Anatomical distribution of fluid introduced at bron- $\frac{}{3}$ choalveolar lavage. Thorax 1987;42:625-9.

13 Hunninghake GW, Crystal RG. Pulmonary sarcoidosis. A disorder mediated by excess helper T-lymphocyte activity at sites of disease activity. $N$ Engl Med $J \vec{\partial}$ 1981;305:429-34.

14 Davis GS, Giancola MS, Constanza MC, Low RB. $\stackrel{?}{\times}$ Analysis of segmental bronchoalveolar lavage samples from healthy human volunteers. Am Rev Respir Dis 1982;126:611-6.

15 Miyashita M, Kawanami T, Matsuda T, et al. A new method of cell analysis in bronchoalveolar lavage with a 음 direct correlation to histological alterations. In: International conference on bronchoalveolar lavage: program and abstracts. Betheseda, Maryland: National Heart, Lung and Blood Institute, 1984:109.

16 Mitchell DN, Scadding JG. Sarcoidosis. Am Rev Respir N Dis 1974;110:774-802.

17 Hatch GE, Gardiner DE, Menzel DB. Chemiluminescence of phagocytic cells caused by $N$-formyl methionyl peptides. J Exp Med 1978;147:182-7.

18 Stevens P, Winston DJ, Van Dyke K. In vitro evaluation of opsonic and cellular granulocyte function by luminol-dependent chemiluminescence: utility in $T$ patients with severe neutropaenia and cellular $\bar{O}$ deficiency states. Infect Immunol 1978;22:41-51.

19 Wallaert B, Bonnière B, Prin L, Cortot A, Tonnel AB, $\frac{\rho}{\mathbb{D}}$ Voisin C. Primary biliary cirrhosis: subclinical inflam- $\varrho$ matory alveolitis in patients with normal chest roentgenograms. Chest 1986;90:842-8. 
Pulmonary macrophage and neutrophil function in sequential bronchoalveolar lavage aspirates in sarcoidosis 791

20 Wallaert B, Aerts C, Bart F, et al. Alveolar macrophage dysfunction in systemic lupus erythematosus. Am Rev Respir Dis 1987;136:293-7.

21 Venet M, Wewers M, Crystal R. Enhanced antigen presentation by alveolar macrophages in patients with sarcoidosis. Clin Res 1982;30:360-7.

22 Crystal RG, Roberts WC, Hunninghake GW, Gadek JE,
Fulmer JD, Line B. Pulmonary sarcoidosis: a disorder characterised by and perpetuated by active lung $T$ lymphocytes. Ann Intern Med 1981;94:73-94.

23 Campbell DA, Poulter L, du Bois RM. Phenotypic analysis of alveolar macrophages in normal subjects and in patients with interstitial lung disease. Thorax 1986;41:429-34. 